\title{
Evaluasi Penerimaan Sistem Perencanaan dan Penilaian Anak Didik Menggunakan Technology Acceptance Model
}

\author{
Muhammad Alkaff $^{1}$, Muti'a Maulida ${ }^{2}$, Arina Ihda Rahmah Syarifah ${ }^{3}$ \\ ${ }^{1,2,3}$ Program Studi Teknologi Informasi, Universitas Lambung Mangkurat, Banjarmasin, Indonesia \\ 1m.alkaff@ulm.ac.id, ${ }^{2}$ mutia.maulida@ulm.ac.id, ${ }^{3}$ arinaihdars@gmail.com
}

Diterima 04 Mei 2020

Disetujui 11 Februari 2021

\begin{abstract}
Most teachers have difficulty in developing Learning Implementation Plans (RPP) due to the large number of instruments in the RPP that need to be made and adapted to the standard format. Likewise, when evaluating students, teachers need to look back at the lesson plan before conducting an assessment. Teacher activities in making lesson plans and assessing according to lesson plans are very time-consuming. Therefore, the Learning Planning and Assessment System for Students (SPADIK) was developed. This new application aimed to ease teacher effort in making learning plans and assessments for students at TK Khalifah Banjarmasin II. The teacher always welcomes the existence of new technology that can help their work. However, if the teacher cannot operate this new technology, they will certainly be in vain. Therefore, evaluation of acceptance of the SPADIK system is required by using the Technology Acceptance Model (TAM). This study uses a qualitative approach by conducting interviews with six kindergarten teachers of Khalifah Banjarmasin II, where this system was implemented. Data from interviews with teachers then reduced to a short description following the variables in the TAM model. From the results of testing with the TAM model, it was concluded that SPADIK could be accepted and used well by the teachers.
\end{abstract}

Index Terms - evaluation; information system; RPP; students assessment; Technnology Acceptance Model (TAM)

\section{PENDAHULUAN}

Dalam membuat perencanaan pembelajaran, guruguru di TK Khalifah Banjarmasin II sebagai satuan pendidikan yang berada di dalam ranah hukum Indonesia [1], menggunakan Permendikbud nomor 137 tahun 2014 sebagai acuan dalam pembuatan rencana pembelajaran harian (RPPH), mingguan (RPPM) dan bulanan, dan semester dan tahunan (PROSEM) [2]. Dalam pembuatannya, guru menggunakan aplikasi pengolah dokumen yang umum digunakan yaitu Microsoft Word atau Microsoft Excel.

Dari banyaknya perencanaan pembelajaran yang dibuat dan penilaian yang dilakukan setiap hari membuat proses menjadi kompleks karena banyaknya instrumen pada RPPH yang harus dibuat sendiri dan harus disesuaikan dengan format penilaian yang umum digunakan guru. Juga dalam pembuatan RPPM, guru harus mencari kembali dan mengetik ulang instrumen yang ada RPPH ke dalam RPPM, dan seterusnya.

Penilaian pembelajaran anak didik dibuat berdasarkan pada rencana pembelajaran yang digunakan oleh guru. Rencana pembelajaran sendiri memuat Kompetensi Inti, Kompetensi Dasar, dan indikator yang akan digunakan untuk menilai perkembangan anak didik sesuai dengan Standar Tingkat Pencapaian Perkembangan Anak yaitu kriteria tentang kemampuan yang dicapai anak pada seluruh aspek perkembangan dan pertumbuhan, yang telah disusun menjadi struktur kurikulum yang disebut Kurikulum 2013 Pendidikan Anak Usia Dini (PAUD) [3].

Sehingga dibuatlah sistem Perencanaan Pembelajaran dan Penilaian Anak Didik (SPADIK) yang berisi fungsi untuk pembuatan rencana pembelajaraan harian dan sistem untuk melakukan penilaian dan evaluasi anak didik yang sudah berbasis pada aspek-aspek dalam rencana pembelajaran yang telah dibuat pada sistem.

Tetapi, meskipun sistem ini telah menjadi salah satu solusi permasalahan, masalah tetap tidak akan terpecahkan apabila sistem tidak dapat diterima dengan baik oleh pengguna. Umumnya, konsep teknologi baru akan diterima dengan baik, jika kemungkinan adanya masalah pada teknologi tersebut, maka itu hanya berhubungan dengan praktik terhadap teknologi atau implementasi yang direalisasikan oleh pengguna [4].

Untuk mengetahui penerimaan pengguna terhadap sistem digunakan model penerimaan Technology Acceptance Model (TAM). TAM adalah model yang paling banyak digunakan dalam lingkup sistem informasi (IS) untuk mengukur penerimaan teknologi karena dinilai memiliki validitas yang tinggi [5], dan 
telah menjadi model yang paling sering dikutip dan berpengaruh untuk memahami penerimaan teknologi baru dan telah menerima dukungan empiris yang luas [6] yang dibuktikan dengan banyaknya penelitian sebelumnya tentang pengukuran penerimaan teknologi menggunakan model TAM [7].

Berdasarkan latar belakang dan berbagai penelitian tentang penerimaan sistem diatas, maka penelitian ini mengusulkan penggunaan Technology Acceptance Model (TAM) untuk melakukan evaluasi penerimaan terhadap Sistem Perencanaan dan Penilaian Anak Didik karena sistem ini menjadi teknologi yang baru diluncurkan dalam konteks khusus di TK Khalifah Banjarmasin II.

\section{Metode PenElitian}

Penelitian ini menggunakan pendekatan kualitatif yaitu penelitian yang bermaksud untuk memahami fenomena tentang apa yang dialami oleh subjek penelitian [8]. Pengumpulan data dengan menggunakan metode wawancara pada 6 orang responden atau informan yang telah dipilih dengan kriteria yang sesuai dengan keperluan penelitian sehingga menghasilkan data yang valid. Keenam informan ini adalah semua tenaga pengajar TK yang menggunakan SPADIK sejak pertama dikenalkan. Informan dipilih sesuai dengan job desk masingmasing di sekolah sehingga peneliti dapat menentukan siapa saja yang akan menggunakan aplikasi ini sesuai dengan kebutuhan pekerjaannya, jadi ketika mencari hasil dalam beberapa waktu mereka menggunakan aplikasi ini, maka hasilnya juga valid karena memang sudah diteliti dari awal mana yang memang memakai aplikasi ini mana yang tidak. Dalam hal ini yaitu guru-guru yang menjadi sasaran pengguna sistem.

Setelah sistem dibuat dan dijalankan oleh pengguna, peneliti melakukan evaluasi dengan wawancara kepada pengguna yang menjadi responden dalam penelitian ini. Instrumen evaluasi dibuat berdasarkan pada model Technology Acceptance Model (TAM) untuk penerimaan sistem baru yang dikemukakan oleh Davis dan Venkatesh [11] pada Gambar 1.

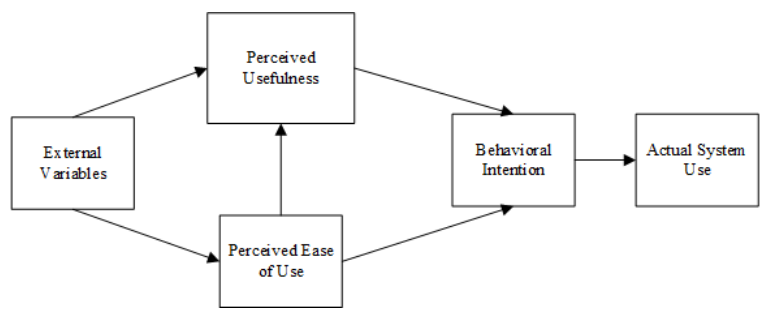

Gambar 1. Model TAM [11]
Variabel-variabel yang digunakan dalam model ini adalah sebagai berikut:

\section{Perceived Usefulness}

Sejalan dengan kata berguna, yang berarti mampu digunakan secara menguntungkan, persepsi kegunaan didefinisikan sebagai sejauh mana seseorang yakin bahwa menggunakan sistem akan meningkatkan kinerjanya [12].

\section{Perceived Ease of Use}

Persepsi kemudahan penggunaan didefinisikan sebagai sejauh mana keyakinan seseorang bahwa penggunaan sistem adalah mudah. Serta diartikan sebagai tingkat seseorang percaya bahwa menggunakan sistem tidak diperlukan usaha apapun (free of effort)[12].

\section{Behavioral Intention}

Menurut Davis dan Venkatesh yang dikutip oleh Wiguna [9] bahwa minat atau niat perilaku pengguna adalah fungsi dari persepsi kegunaan dan persepsi kemudahan penggunaan. Intention atau niat semacam itu secara spesifik dapat disebut tujuan implementasi, yaitu berniat menggunakan sistem di tempat kerja untuk meningkatkan kinerja di tempat kerja [11].

\section{Actual System Use}

Menurut Sykes yang dikutip oleh Wiguna [9], penggunaan yang sebenarnya adalah hasil perilaku obyektif yang diukur sebagai jumlah waktu seseorang terlibat dalam interaksi langsung dengan sistem.

\section{External Variabel}

Pada penelitian ini peneliti menggunakan 3 eksternal variabel diantaranya:

a. Kesesuaian Fungsi

Kesesuaian fungsi didefinisikan sebagai koresponden antara kebutuhan tugas, kemampuan individual dan fungsi dari teknologi. Kesesuaian tugas dan teknologi dipengaruhi oleh interaksi antara karakteristik individu pemakai, teknologi yang digunakan, dan tugas yang berbasis teknologi [11].

b. Pengalaman Pengguna

Kajian Taylor dan Todd yang dikutip oleh Hakim [11], menyatakan bahwa pengguna yang berpengalaman menunjukan bahwa ada korelasi yang kuat antara minat menggunakan suatu teknologi dan perilaku penggunaan suatu teknologi.

c. Rancangan Antarmuka

Menurut Santosa yang dikutip oleh Putra [12], Pembuatan antarmuka sistem harus bertujuan untuk memudahkan penggunaan oleh pengguna 
atau disebut dengan istilah user friendly, yang menunjuk kepada kemampuan yang dimiliki oleh perangkat lunak atau program aplikasi yang mudah dioperasikan.

Variabel ini kemudian dijadikan sebagai instrumen evaluasi yang kemudian dibuat item pertanyaan untuk wawancara terhadap responden, yang dapat dilihat pada Tabel 1 sebagai berikut.

Tabel 1. Variabel dan item evaluasi

\begin{tabular}{|c|c|}
\hline Variabel & Item Evaluasi \\
\hline Persepsi kegunaan [10] [11] & 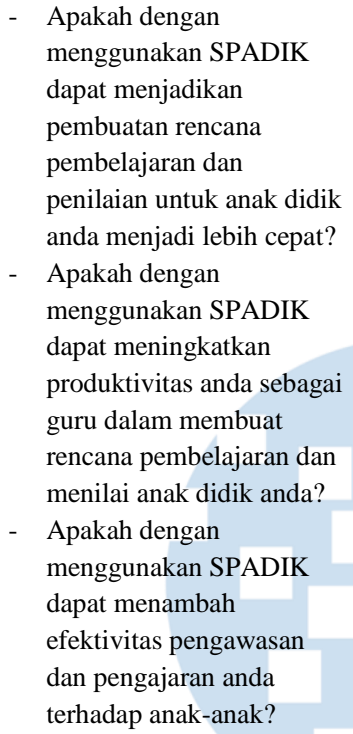 \\
\hline $\begin{array}{l}\text { Persepsi kemudahan } \\
\text { penggunaan [10] [11] }\end{array}$ & 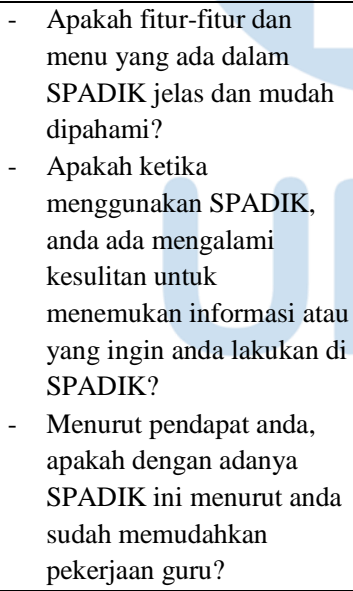 \\
\hline $\begin{array}{l}\text { Intensitas perilaku } \\
\text { penggunaan [10] }\end{array}$ & 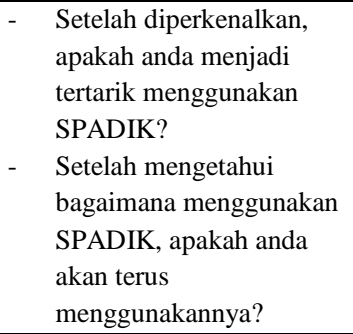 \\
\hline $\begin{array}{c}\text { Penggunaan secara aktual } \\
{[10]}\end{array}$ & $\begin{array}{l}\text { Apakah dengan menggunakan } \\
\text { SPADIK, pembuatan rencana } \\
\text { pembelajaran dan menilai } \\
\text { anak dapat selesai dengan } \\
\text { cepat? }\end{array}$ \\
\hline $\begin{array}{c}\text { Pengalaman penggunaan } \\
{[12]}\end{array}$ & $\begin{array}{l}\text { Apakah anda pernah } \\
\text { menggunakan sistem }\end{array}$ \\
\hline
\end{tabular}

\begin{tabular}{|c|c|}
\hline & $\begin{array}{l}\text { berbasis web yang seperti } \\
\text { SPADIK? } \\
\text { - } \text { Bagaimana menurut anda } \\
\text { pembuatan rencana } \\
\text { pembelajaran dengan } \\
\text { menggunakan SPADIK } \\
\text { dan dengan cara yang } \\
\text { biasanya? }\end{array}$ \\
\hline Rancangan antarmuka [12] & $\begin{array}{l}\text { - } \\
\text { Apakah dengan } \\
\text { menggunakan SPADIK, } \\
\text { anda dapat lebih mudah } \\
\text { mendapatkan informasi? } \\
\text { - } \quad \text { Bagaimana pendapat anda } \\
\text { mengenai pembuatan RPP } \\
\text { dan penilaian anak yang } \\
\text { sudah didigitalkan dengan } \\
\text { SPADIK? }\end{array}$ \\
\hline Kesesuaian fungsi [12] & 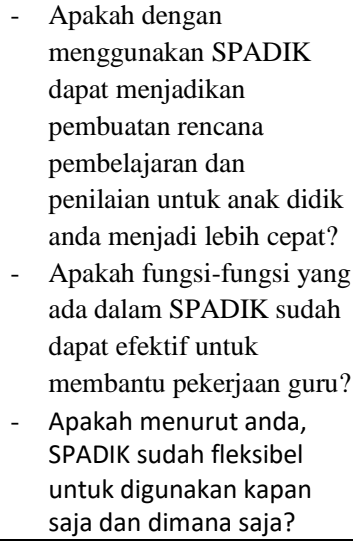 \\
\hline
\end{tabular}

Data yang dikumpulkan dari evaluasi kemudian di analisis untuk mendapatkan tujuan penelitian. Dalam penelitian kualitatif, analisis data adalah proses pengorganisasikan dan mengurutkan data ke dalam pola, katagori, dan satuan uraian dasar seperti yang dikemukakan oleh Saldana [7] yang di gambarkan pada Gambar 2 berikut.

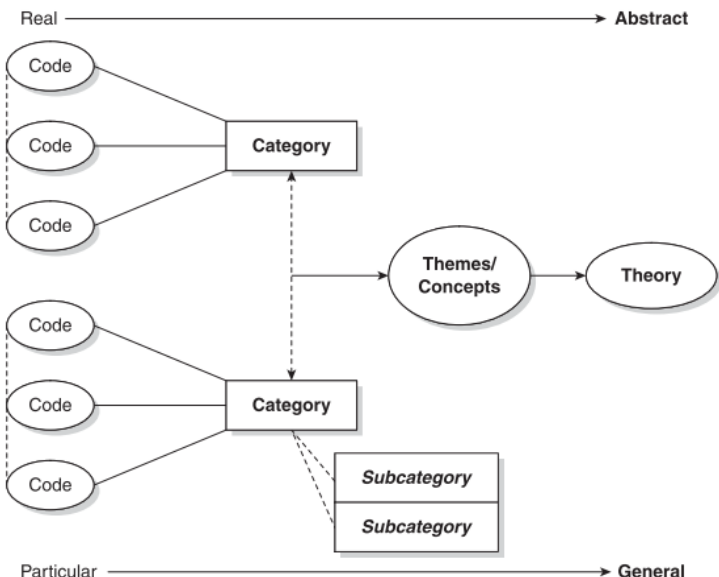

Gambar 2. Alur analisis data kualitatif [7]

Tahap pertama analisis data adalah reduksi data atau meringkas data. Dalam penelitian ini yang akan 
diringkas adalah data wawancara evaluasi sistem. Sebelumnya, peneliti akan melakukan pengkodean terhadap informan, untuk memudahan pengkodean selanjutnya [7]. Kemudian dilakukan pengkodean terhadap hasil wawancara sehingga didapatkan tanggapan-tanggapan responden tentang penerimaan sistem. Lalu disetiap kode tanggapan dijadikan interpretasi supaya memudahkan peneliti dalam menerjemahkan kalimat langsung menjadi kalimat penulisan [8]. Dari interpretasi tersebut dijadikan kategori yang menyesuaikan dengan variabel model yang digunakan, sehingga didapatkan persentase tanggapan yang muncul dari evaluasi oleh responden.

Tabel 2. Contoh pengkodean pernyataan

\begin{tabular}{|c|c|c|}
\hline Kode & Pernyataan & Interpretasi \\
\hline K1 & $\begin{array}{l}\text { G4: "Membuat rpphnya sudah pas } \\
\text { saja yang seperti biasanya, } \\
\text { penilaiannya juga" }\end{array}$ & $\begin{array}{l}\text { Sistem sudah } \\
\text { sesuai }\end{array}$ \\
\hline $\mathrm{K} 2$ & $\begin{array}{l}\text { G5: "Membuatnya mudah, klik } \\
\text { yang ini, yang ini, sudah jadi di } \\
\text { sistemnya" }\end{array}$ & $\begin{array}{l}\text { Sistem sangat } \\
\text { mudah }\end{array}$ \\
\hline K3 & $\begin{array}{l}\text { G1: "Keliatan nih siapa aja guru } \\
\text { yang sudah membuat rpph untuk } \\
\text { seminggu misalnya" }\end{array}$ & $\begin{array}{l}\text { Informasi mudah } \\
\text { didapatkan }\end{array}$ \\
\hline K4 & $\begin{array}{l}\text { G2: "Kalau membuatnya cepat } \\
\text { selesai, berarti bisa mengerjakan } \\
\text { pekerjaan yang lain juga" }\end{array}$ & $\begin{array}{l}\text { Membantu } \\
\text { pekerjaan }\end{array}$ \\
\hline K5 & $\begin{array}{l}\text { G3: "Saya jadi semangat membuat } \\
\text { rpph dengan adanya sistem" }\end{array}$ & $\begin{array}{l}\text { Semangat } \\
\text { menggunakan } \\
\text { sistem }\end{array}$ \\
\hline K6 & G2: "Yang pasti efektif waktu" & Hemat waktu \\
\hline Ket. & $\begin{array}{l}\mathrm{K} 1, \mathrm{~K} 2, . .=\text { Pengkodean } \\
\mathrm{G} 1, \mathrm{G} 2, . .=\text { Pengkodean }\end{array}$ & taan \\
\hline
\end{tabular}

Menurut Richards dan Morse yang dikutip oleh Saldana [7], mengkodekan data bukan hanya untuk inisialisasi, tapi untuk mendapatkan hubungan antar data sehingga didapatkan ide, selanjutnya didapatkan data yang berkaitan dengan ide. Melakukan kode juga untuk menentukan kategori sehingga data lebih terorganisasi [7]. Setelah kategori utama berhasil didapatkan dan di bandingkan dengan kategori lainnya, dilakukan penyusunan konsep dan teori sesuai dengan model penelitian, dalam hal ini yaitu model Technology Acceptance Model (TAM). Untuk merealisasikan penelitian kualitatif, hasil penemuan kualitatif dapat digeneralisasikan dengan didasari pada penyusunan teori [8].

\section{HASIL DAN PEMBAHASAN}

Setelah melalui proses wawancara didapatkan hasil berupa 76 kategori pernyataan yang dikemukakan oleh responden untuk kemudian diinterpretasikan

yang digunakan.

\section{A. Persepsi Kegunaan}

Tabel 3. Hasil persepsi kegunaan

\begin{tabular}{|c|c|c|c|}
\hline Kode & Interpretasi & $\mathbf{F}$ & $\mathbf{P}$ \\
\hline $\mathrm{K} 1, \mathrm{~K} 3, \mathrm{~K} 66$ & $\begin{array}{c}\text { Sistem sangat } \\
\text { membantu }\end{array}$ & 3 & $21,43 \%$ \\
\hline $\begin{array}{c}\mathrm{K} 5, \mathrm{~K} 23, \mathrm{~K} 24, \\
\mathrm{~K} 26, \mathrm{~K} 41, \mathrm{~K} 42, \\
\mathrm{~K} 54\end{array}$ & $\begin{array}{c}\text { Sistem sangat } \\
\text { mudah }\end{array}$ & 7 & $50 \%$ \\
\hline $\mathrm{K} 7, \mathrm{~K} 9$ & $\begin{array}{c}\text { Membantu } \\
\text { pekerjaan }\end{array}$ & 2 & $14,29 \%$ \\
\hline $\mathrm{K} 73$ & $\begin{array}{c}\text { Sistem kurang } \\
\text { lengkap }\end{array}$ & 1 & $7,14 \%$ \\
\hline $\mathrm{K} 74$ & $\begin{array}{c}\text { Hasil kurang } \\
\text { sesuai }\end{array}$ & 1 & $7,14 \%$ \\
\hline
\end{tabular}

\section{Keterangan: $\quad F=$ Frekuensi \\ $\mathrm{P}=$ Persentase}

Berdasarkan hasil penelitian, kategori persepsi kegunaan dapat diketahui dari tanggapan-tanggapan rensonden yang selaras dengan teori Persepsi Kegunaan dari model TAM. Persepsi kegunaan menurut Davis adalah ketika seorang yakin bahwa sistem yang digunakan dapat meningkatkan kinerjanya. Dalam hal ini, yaitu sistem perencanaan pembelajaran dan penilaian anak didik (SPADIK) yang dapat membantu pekerjaan pembuatan rencana pelaksanaan pembelajaran (RPP) oleh guru menjadi lebih mudah.

Dari Tabel 3 diketahui bahwa terdapat 14 kode pernyataan yang sesuai dengan ketegori persepsi kegunaan. Berdasarkan hasil tersebut disimpulkan bahwa pernyataan sistem sangat mudah digunakan paling banyak disebutkan oleh responden. Sehingga persepsi kegunaan mempengaruhi penerimaan pengguna terhadap SPADIK.

\section{B. Persepsi Kemudahan}

Pada persepsi kemudahan penggunaan digambarkan oleh Davis bahwa seorang yakin bahwa sistem itu mudah digunakan dan tidak membutuhkan upaya yang besar untuk menggunakan sistem tersebut.

Tabel 4. Hasil persepsi kemudahan

\begin{tabular}{|c|c|c|c|}
\hline Kode & Interpretasi & F & P \\
\hline K12, K13 & $\begin{array}{c}\text { Mengerti } \\
\text { operasional } \\
\text { sistem }\end{array}$ & 2 & $8,69 \%$ \\
\hline $\begin{array}{c}\text { K14, K16, } \\
\text { K18, K19, } \\
\text { K34 }\end{array}$ & $\begin{array}{c}\text { Mudah } \\
\text { menggunakannya }\end{array}$ & 5 & $21,74 \%$ \\
\hline
\end{tabular}




\begin{tabular}{|c|c|c|c|}
\hline $\begin{array}{c}\text { K15, K17, } \\
\text { K56, K58 }\end{array}$ & $\begin{array}{c}\text { Paham dengan } \\
\text { sistem }\end{array}$ & 4 & $17,39 \%$ \\
\hline $\begin{array}{c}\text { K36, K38, } \\
\text { K48, K49, } \\
\text { K50 }\end{array}$ & $\begin{array}{c}\text { Akses sistem } \\
\text { mudah }\end{array}$ & 5 & $21,74 \%$ \\
\hline K25 & $\begin{array}{c}\text { Pembuatannya } \\
\text { mudah }\end{array}$ & 1 & $4,35 \%$ \\
\hline K27 & $\begin{array}{c}\text { Tugas cepat } \\
\text { selesai }\end{array}$ & 1 & $4,35 \%$ \\
\hline K28 & $\begin{array}{c}\text { Memudahkan } \\
\text { pekerjaan }\end{array}$ & 1 & $4,35 \%$ \\
\hline $\begin{array}{c}\text { K6, K65, K67, } \\
\text { K68 }\end{array}$ & $\begin{array}{c}\text { Informasi mudah } \\
\text { didapatkan }\end{array}$ & 4 & $17,39 \%$ \\
\hline
\end{tabular}

\begin{tabular}{|c|c|c|c|}
\hline & perintah aturan & & \\
\hline $\begin{array}{c}\text { K69, K70, } \\
\text { K75 }\end{array}$ & Kesiapan guru & 3 & $30 \%$ \\
\hline
\end{tabular}

Setelah dilakukan evaluasi, dilihat dari Tabel 5 terdapat 10 pernyataan dari responden yang menunjukkan tentang niat, minat, dan keinginan mereka dalam penggunan sistem SPADIK. Dalam kategori ini sebanyak 3 pernyataan yang mengungkapkan bahwa mereka menjadi semangat menggunakan sistem setelah mengetahui manfaat sistem dan bagaimana sistem bekerja. Tanggapan ini merupakan tanggapan yang paling banyak dikemukakan oleh responden. Hanya saja niat perilaku penggunaan ini mendapatkan tanggapan negatif yang merupakan tanggapan yang sama banyaknya dikemukakan oleh responden yaitu sebanyak 3 tanggapan yaitu kesiapan guru dalam membuat RPPH di dalam sistem. Akan tetapi, tanggapan negatif ini dapat diperbaiki dengan banyaknya tanggapan yang menyatakan bahwa mereka memiliki niat dan minat yang besar untuk menggunakan sistem berdasarkan berbagai tanggapan yang dikemukakan oleh responden lainnya.

Niat perilaku pengguna juga digambarkan bahwa seorang pengguna berniat atau mempunyai minat untuk berinteraksi dengan sistem. Hal ini mempengaruhi penggunaan aktual sistem. Penggunaan aktual sistem mendapat pengaruh dari niat perilaku pengguna yang menggunakan sistem dalam konteks frekuensi penggunaan sistem. Karena dengan adanya minat dan ketertarikan guru dalam menggunakan sistem, maka sistem akan lebih sering digunakan. SPADIK dinilai telah menarik minat penggunaan guru, sehingga sistem terus digunakan oleh guru. Seperti yang diungkapkan oleh responden yang mengakui bahwa mereka menjadi lebih bersemangat mengerjakan kewajiban pembuatan RPPH dengan menggunakan sistem. Sehingga niat dan minat perilaku penggunaan sistem dapat mempengaruhi penggunaan aktual sistem.

\section{Penggunaan Aktual Sistem}

Penggunaan secara aktual adalah hasil perilaku obyektif yang diukur sebagai jumlah waktu seorang terlibat dalam interaksi langsung dengan sistem.

Tabel 6. Hasil persepsi penggunaan aktual sistem

Tabel 5. Hasil persepsi niat perilaku

\begin{tabular}{|c|c|c|c|}
\hline Kode & Interpretasi & $\mathbf{F}$ & $\mathbf{P}$ \\
\hline K33 & Sistem itu perlu & 1 & $10 \%$ \\
\hline K62 & $\begin{array}{c}\text { Sistem } \\
\text { digunakan }\end{array}$ & 1 & $10 \%$ \\
\hline K8, K35, K61 & $\begin{array}{c}\text { Semangat } \\
\text { menggunakan } \\
\text { sistem }\end{array}$ & 3 & $30 \%$ \\
\hline K60 & Ingin tahu & 1 & $10 \%$ \\
\hline K68 & Mengikuti & 1 & $10 \%$ \\
\hline
\end{tabular}

\begin{tabular}{|c|c|c|c|}
\hline Kode & Interpretasi & F & P \\
\hline K10, K43 & $\begin{array}{c}\text { Penggunaannya } \\
\text { hemat waktu }\end{array}$ & 2 & $10 \%$ \\
\hline K44 & $\begin{array}{c}\text { Penggunaan } \\
\text { sesuai keperluan }\end{array}$ & 1 & $10 \%$ \\
\hline K46 & $\begin{array}{c}\text { Penggunaan } \\
\text { fleksibel }\end{array}$ & 1 & $30 \%$ \\
\hline K47 & $\begin{array}{c}\text { Lebih cepat dari } \\
\text { cara manual }\end{array}$ & 1 & $10 \%$ \\
\hline K76 & Akses sulit jika & 1 & $10 \%$ \\
\hline
\end{tabular}

30 Ultima InfoSys : Jurnal Ilmu Sistem Informasi, Vol. 12, No. 1 | Juni 2021 
tidak ada koneksi

Berdasarkan Tabel 6 diketahui hasil dari evaluasi penerimaan sistem kategori penggunaan aktual. Peneliti mendapatkan 6 pernyataan yang dikemukakan responden yang mengungkapkan tentang waktu responden dalam berinteraksi dengan SPADIK. Sebanyak 2 pernyataan yang merupakan pernyataan yang banyak dikemukan oleh responden yaitu bahwa penggunaan sistem menghemat waktu pengguna. Pernyataan dalam evaluasi ini telah dibandingkan dengan histori input data dalam database sistem sebagai pembuktian penggunaan sistem.

Dalam penggunaannya selama 3 minggu, sistem telah menerima sejumlah data pembuatan RPPH, yang dilakukan oleh pengguna. Hal ini menyatakan bahwa ada peningkatan penggunaan dari minggu pertama. Selain itu, dari pernyataan responden dapat diambil bahwa interaksi responden dengan sistem tergantung dari kesiapan responden sebagai guru dalam mengisikan rencana pembelajarannya.

Jika guru sudah siap dengan bahan-bahan yang akan di ajarkan, maka pembuatan RPPH dapat selesai dengan cepat dan dapat membuat RPPH hari lainnya atau langsung melakukan penilaian. Sebaliknya jika guru belum siap dengan bahan pembelajaran yang akan diisikan ke sistem, proses pembuatan juga menjadi lebih lambat. Sehingga penggunaan sistem secara aktual dipegaruhi oleh kesiapan guru dalam menyiapkan bahan pembelajaran.

\section{E. Pengalaman Penggunaan}

Kajian Ajzein dan Fishbein yang menemukan adanya perbedaaan yang signifikan antara pengguna yang berpengalaman dengan yang tidak berpengalaman dalam penggunaan sistem.

Tabel 7. Hasil persepsi pengalaman penggunaan

\begin{tabular}{|c|c|c|c|}
\hline Kode & Interpretasi & F & P \\
\hline K29 & $\begin{array}{c}\text { Paham dengan } \\
\text { sistem }\end{array}$ & 1 & $25 \%$ \\
\hline K67 632 & $\begin{array}{c}\text { Familiar dengan } \\
\text { aplikasi web }\end{array}$ & 2 & $50 \%$ \\
\hline K72 & $\begin{array}{c}\text { Kurang bisa } \\
\text { mengunakan } \\
\text { teknologi }\end{array}$ & 1 & $25 \%$ \\
\hline $\begin{array}{c}\text { Kurang } \\
\text { pengalaman } \\
\text { dengan sistem }\end{array}$ & 1 & $25 \%$ \\
\hline
\end{tabular}

Berdasarkan Tabel 7 diketahui bahwa terdapat 5 pernyataan yang menyinggung tentang pengalaman penggunaan mereka dalam menggunakan sistem. Sebanyak 2 pernyataan dikemukakan oleh responden bahwa mereka telah terbiasa dengan sistem atau aplikasi berbasis web seperti SPADIK. Tetapi meskipun guru tidak terbiasa atau kurang pengalaman dengan sistem, responden menyatakan bahwa mereka dapat memahami sistem dengan baik. Kemudahan penggunaan dari sistem dapat membantu untuk meningkatkan pengalaman penggunanya terhadap sistem.

\section{F. Rancangan Antarmuka}

Dalam pembuatan rancangan antarmuka harus bertujuan untuk memudahkan penggunaan oleh pengguna (user friendly), sehingga sistem atau aplikasi tersebut mudah dioperasikan. Rancangan antarmuka menjadi salah satu yang diperhatikan oleh responden karena pengguna berinteraksi secara langsung melalui antarmuka sistem.

Tabel 8. Hasil persepsi rancangan antarmuka

\begin{tabular}{|c|c|c|c|}
\hline Kode & Interpretasi & $\mathbf{F}$ & $\mathbf{P}$ \\
\hline $\begin{array}{l}\text { K20, K21, } \\
\text { K22, K37, } \\
\text { K39, K45 }\end{array}$ & $\begin{array}{l}\text { Operasi sistem } \\
\text { mudah }\end{array}$ & 6 & $54,54 \%$ \\
\hline K40 & $\begin{array}{l}\text { Sistem mudah } \\
\text { dipahami }\end{array}$ & 1 & $9,09 \%$ \\
\hline K51, K53 & Sistem fleksibel & 2 & $18,18 \%$ \\
\hline K52 & $\begin{array}{l}\text { Akses sistem } \\
\text { fleksibel }\end{array}$ & 1 & $9,09 \%$ \\
\hline K71 & $\begin{array}{l}\text { Sistem masih } \\
\text { perlu } \\
\text { pembaharuan }\end{array}$ & 1 & $9,09 \%$ \\
\hline
\end{tabular}

Dari Tabel 8 diketahui bahwa terdapat 11 pernyataan yang menunjukkan kesan responden terhadap rancangan antarmuka SPADIK. Dengan kemudahan operasional dan kemudahan antarmuka membuat sistem mudah dipahami dan digunakan.

Dalam pembuatannya, sistem ini menggunakan konsep warna khas TK Khalifah, yang diaplikasikan ke antarmuka sistem. Dan untuk fitur-fitur yang ada, sudah dirancang dengan antarmuka yang simple dan familiar, supaya informasi dalam sistem mudah didapatkan dan kegunaan sistem terpenuhi. Sehingga untuk rancangan antarmuka juga berpengaruh terhadap kemudahan penggunaan. Seperti yang diungkapkan responden pada pembahasan tentang rancangan antarmuka, bahwa sistem itu mudah digunakan karena responden sudah tahu bagaimana menggunakan sistem dan apa yang dilakukan dengan sistem.

\section{G. Kesesuaian Fungsi}

Tabel 9. Hasil persepsi kesesuaian fungsi

\begin{tabular}{|c|c|c|c|}
\hline Kode & Interpretasi & F & P \\
\hline K2, K4 & $\begin{array}{c}\text { Sistem sudah } \\
\text { sesuai }\end{array}$ & 2 & $25 \%$ \\
\hline
\end{tabular}


ISSN 2085-4579

\begin{tabular}{|c|c|c|c|}
\hline K31 & $\begin{array}{c}\text { Bisa } \\
\text { menggunakan } \\
\text { sistem }\end{array}$ & 1 & $12,5 \%$ \\
\hline K63 & Informasi jelas & 1 & $12,5 \%$ \\
\hline K64 & $\begin{array}{c}\text { Informasi mudah } \\
\text { dipahami }\end{array}$ & 1 & $12,5 \%$ \\
\hline $\begin{array}{c}\text { K55, K57, } \\
\text { K59 }\end{array}$ & $\begin{array}{c}\text { Fungsi sistem } \\
\text { sesuai }\end{array}$ & 3 & $37,5 \%$ \\
\hline
\end{tabular}

Kesesuaian fungsi sistem karena adanya hubungan antara kebutuhan tugas, kemampuan individual dan fungsi dari sistem itu sendiri. SPADIK difungsikan untuk dapat membantu pembuatan RPPH guru dan membantu record untuk penilaian anak didik TK Khalifah Banjarmasin II. Kesesuaian fungsi sistem ini dapat dilihat dari banyaknya tanggapan responden tentang kemudahan penggunaan sistem. Berdasarkan hasil evaluasi diketahui bahwa 8 pernyataan dari responden yang menyatakan tentang kesesuaian fungsi SPADIK. Sebanyak 3 pernyataan yang diungkapkan oleh responden bahwa fungsi sistem sudah sesuai. Responden menerangkan bahwa fungsi sistem tidak menyimpang dari pembelajaran yang ada. Sehingga kesesuaian fungsi SPADIK telah terpenuhi. Selain itu, berdasarkan analisis hasil data dan deskripsi pembahasan tentang kesesuaian fungsi sistem diatas, fungsi-fungsi yang ada pada sistem sudah sangat jelas dan mudah dalam pengoperasian sehingga kegunaan sistem dapat dijalankan dengan baik. Yang berarti bahwa kesesuaian fungsi sangat perpengaruh terhadap kegunaan sistem. Kesesuaian fungsi ditunjukkan pada fungsi utama sistem SPADIK, dalam hal ini yaitu pembuatan rencana pembelajaran dan penilaian anak didik. Keberhasilan berjalannya fungsi-fungsi ini menjadi pengaruh bagi kegunaan sistem. Singkatnya, jika fungsi sistem tidak sesuai dengan yang dijadikan tujuan, maka sistem itu menjadi tidak berguna. Guru dapat menerima sistem karena sudah memenuhi fungsinya dan sesuai dengan tujuan, sehingga dapat digunakan dengan baik oleh pengguna.

\section{H. Penerimaan Sistem}

Penerimaan sistem didasari dari variabel yang digunakan pada model penerimaan TAM. Dalam hal ini peneliti telah mendapatkan hasil kode dari semua pernyataan sebagaimana dicontohkan pada Tabel 3 yang bernada positif dan negatif. Berikut adalah Tabel 10 yang menjelaskan tanggapan positif dan negatif responden terhadap penerimaan sistem berdasarkan hasil wawancara.

Tabel 10. Penerimaan sistem

\begin{tabular}{|c|c|}
\hline Tanggapan & F \\
\hline Positif & 68 \\
\hline Negatif & 8 \\
\hline
\end{tabular}




\section{Kategori Penerimaan Sistem}

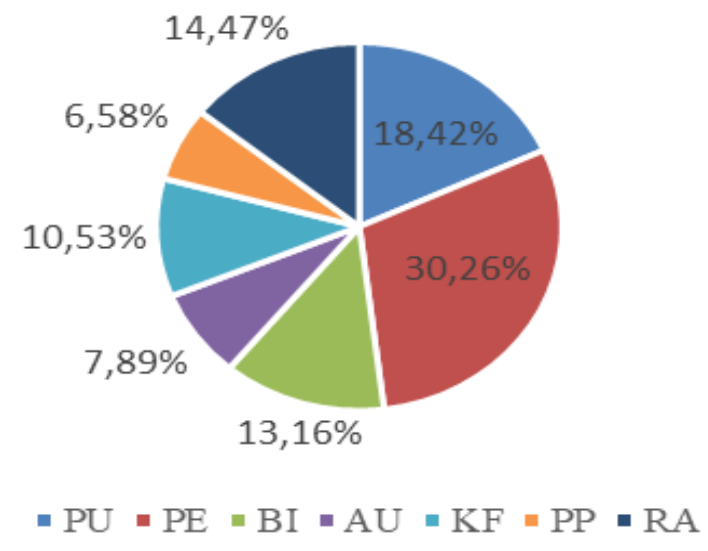

Gambar 4. Diagram kategori penerimaan system

Pada diagram diatas dapat dilihat bahwa persentase persepsi kemudahan (PE) menjadi variabel yang paling banyak diungkapkan dalam penerimaan sistem berdasarkan kategori pernyataan responden. Serta dalam penerimaan oleh responden didapatkan hasil sebagaimana diperlihatkan pada Tabel 12 berikut.

Tabel 12. Penerimaan sistem oleh responden

\begin{tabular}{|c|c|c|}
\hline Kategori & F & P \\
\hline Persepsi Kegunaan (PU) & 6 & $100 \%$ \\
\hline Persepsi Kemudahan (PE) & 6 & $100 \%$ \\
\hline Niat Perilaku (BI) & 4 & $66,67 \%$ \\
\hline Penggunaan Aktual (AU) & 4 & $66,67 \%$ \\
\hline Kesesuaian Fungsi (KF) & 5 & $83,33 \%$ \\
\hline Pengalaman Pengguna (PP) & 3 & $50 \%$ \\
\hline Rancangan Antarmuka (RA) & 5 & $83,33 \%$ \\
\hline
\end{tabular}

Tabel 12 menyatakan responden yang mengungkapkan tanggapan penerimaannya berdasarkan kategori model penerimaan sistem. Persepsi kegunaan dan persepi kemudahan sistem mendapatkan persentase paling tinggi karena semua responden beranggapan bahwa sistem berguna dan sistem mudah digunakan, hanya saja dari segi pengalaman penggunaan, responden masih belum sering menggunakan aplikasi sejenis sehingga untuk persentase pengalaman penggunaan masih rendah.

\section{SIMPULAN}

Dari hasil penelitian dan pembahasan yang diuraikan sebelumnya, dapat diketahui bahwa seluruh guru (6 orang) menerima sistem berdasarkan variabel Persepsi Kegunaan penerimaan sistem. Dalam variabel persepsi kemudahan, 6 orang atau seluruh guru menerima sistem. Dalam variabel Niat perilaku,
4 dari 6 orang $(66,67 \%)$ menerima sistem. Dalam variabel penerimaan sistem Penggunaan Aktual, 4 dari 6 orang $(66,67 \%)$ menerima sistem. Dalam variabel Kesesuaian Fungsi dan Rancangan Antarmuka, mesing-masing memiliki 5 dari 6 orang $(83,33 \%)$ menerima sistem. Dalam variabel Pengalaman Pengguna pada penerimaan sistem, sebanyak 3 dari 6 orang $(50 \%)$ menerima sistem. Penerimaan guru terhadap sisem didasarkan dari respon dan reaksi guru ketika menggunakan sistem dan dari wawancara langsung dengan guru yang diukur dengan menggunakan Technology Acceptance Model (TAM) sebagai model untuk melakukan evaluasi penerimaan guru terhadap SPADIK

Faktor penerimaan guru yang paling berpengaruh adalah faktor kemudahan penggunaan atau persepsi kemudahan penggunaan yaitu sebesar 33,82\% dari semua faktor penerimaan. Selanjutnya adalah persepsi kegunaan yang memiliki pengaruh sebesar $17,65 \%$ dari semua pernyataan penerimaan oleh guru. Kemudian ada faktor rancangan antarmuka yang secara langsung berpengaruh terhadap kemudahan penggunaan, memiliki persentase tanggapan sebanyak $14,71 \%$. Selain itu, masing-masing faktor kesesuaian fungsi, yang memiliki persentase tanggapan sebanyak $11,76 \%$, intensitas perilaku penggunaan yang memiliki 8,82\% tanggapan, penggunaan secara aktual yang memilki $7,35 \%$ tanggapan, dan pengalaman penggunaan yang memiliki paling sedikit pengaruh tanggapan yaitu sebanyak 4,41\%.

Didapatkan bahwa penerimaan guru terhadap sistem dapat diukur dengan menggunakan model penerimaan sehingga dihasilkan bagaimana penerimaan sistem dapat dijelaskan secara ilmiah dengan menggunakan model TAM. Hasil ini dapat menjadi acuan pemeliharaan dan perbaikan untuk pengembangan sistem lebih lanjut. Guru menjadi lebih familiar dengan teknologi sehingga pekerjaan guru menjadi lebih efisien dengan bantuan aplikasi. Saran yang dapat disampaikan pada penelitian ini yaitu, untuk kedepannya Sistem yang ada di TK Khalifah Banjarmasin II menjadi lebih berkembang menjadi sistem yang lebih kompleks, dan untuk responden penelitian peneliti dapat melakukan pemilihan sampel yang lebih luas, misalnya untuk seluruh cabang TK Khalifah.

\section{DAFTAR PUSTAKA}

[1] TK Khalifah, "TK KHALIFAH - TK Islam Favorit - TK Islam Terbaik - Sekolah Unggulan,” 2019.

[2] Kementerian Pendidikan dan Kebudayaan Republik Indonesia, "Peraturan Menteri Pendidikan dan Kebudayaan Republik Indonesia Nomor 137 Tahun 2014 Tentang Standar Nasional Pendidikan Anak Usia Dini," Jakarta: Mendiknas, 2014.

[3] Kementerian Pendidikan dan Kebudayaan Republik Indonesia, "Peraturan Menteri Pendidikan dan Kebudayaan Republik Indonesia Nomor 146 tahun 2014 Tentang Kurikulum 2013 Pendidikan Anak Usia Dini,” 2015. 
[4] S. Aromaa, A. Väätänen, M. Hakkarainen, and E. Kaasinen, "User Experience and User Acceptance of an Augmented Reality Based Knowledge-Sharing Solution in Industrial Maintenance Work BT - Advances in Usability and User Experience," 2018, pp. 145-156.

[5] N. L. N. S. Devi and I. W. Suartana, "Analisis technology acceptance model (TAM) terhadap penggunaan sistem informasi di Nusa Dua Beach Hotel \& SPA," E-Jurnal Akunt., pp. 167-184, 2014.

[6] W.-T. Ku and P.-J. Hsieh, "Investigating Users' Intention to Use Personal Health Management Services: An Empirical Study in Taiwan BT - Human Aspects of IT for the Aged Population. Design for the Elderly and Technology Acceptance," 2019, pp. 228-237.

[7] S. Alharbi and S. Drew, "Using the Technology Acceptance Model in Understanding Academics 'Behavioural Intention to Use Learning Management Systems," vol. 5, no. 1, pp. 143-155, 2014.

[8] Z. A. Hasibuan, Metodologi Penelitian pada Bidang Ilmu
Komputer dan Teknologi Informasi. Fakultas Ilmu Komputer Universitas Indonesia, 2007.

[9] W. Wiguna, "Adopsi Sistem Informasi Akademik Perguruan Tinggi BSI Bandung Berbasis TAM,” J. Inform., vol. 4, no. 2, 2017.

[10] Prihantoro, "Analisis Pemanfaatan Aplikasi Profil Berbasis Web (APPROWEB) dalam rangka Pencapaian Indikator Kinerja Utama Account Representative (AR) di Kantor Pelayanan Pajak Pratama (KPP) Yogyakarta," STIE Widya Wiwaha Yogyakarta, 2017.

[11] K. N. Hakim and B. Hadiprajitno, "Analisis faktor-faktor yang mempengaruhi penerimaan dan penggunaan software akuntansi MYOB dengan menggunakan pendekatan Technology Acceptance Model (TAM)." Universitas Diponegoro, 2011.

[12] S. J. Putra, J. Budiarto, and J. Qudsi, “Analisis Ragam Dialog Diagnosis Penyakit Berbasis SPK Model TAM Dengan SEMPLS," vol. 1, no. 2, 2018. 